Endocrinol. Japon. 1989, 36 (5), 727-731

\title{
Mechanism of Biphasic Action of Mono- and Bivalent Salts on the Binding of Prolactin to the Receptor in the Rabbits Mammary Gland
}

\author{
Senkiti SAKAI AND KaORu KHOMOTO
}

Department of Animal Breeding, Faculty of Agriculture, University of Tokyo, Yayoi 1-1-1, Bunkyo-ku, Tokyo 113, Japan

\begin{abstract}
The influence of $\mathrm{NaCl}, \mathrm{KCl}, \mathrm{CaCl}_{2}$, and $\mathrm{MgCl}_{2}$ on the binding of prolactin (PRL) to its receptor was investigated. The salts were dissolved in a metallic ion-free binding buffer and had biphasic effects on changes in the association rate constant $\left(\mathrm{k}_{+1}\right)$ of PRL binding, depending on their concentrations: there was an increase in the $\mathrm{k}_{+1}$ at lower concentrations and a decrease at higher concentrations. The dissociation rate of bound PRL was unaffected. $\mathrm{NaCl}$ at any concentration did not change the binding capacity. Bivalent salts, at higher than $25 \mathrm{mM}$, increased the capacity about 1.6 -fold as compared to the $0 \mathrm{mM}$ control. By cross-linking the PRL-receptor complex, the band of a molecular weight $\left(\mathrm{M}_{\mathrm{r}}\right) 34,500$ receptor could always be detected on the autoradiogram. An $M_{r} 78,000$ receptor appeared only after incubation with bivalent salts. Data indicate that the binding of PRL to an $M_{r} 78,000$ receptor is directly regulated by bivalent cation.
\end{abstract}

The mammary gland has a specific receptor for prolactin (PRL). The binding of PRL to its receptor is a chemical reaction, and thus the importance of the effect of ions and their ionic strength on the binding of PRL to the receptor has been noted (Shiu and Friesen, 1974; Haro and Talamantes, 1985). However, the effects of ions and their ionic strength on the association and dissociation of PRL have not been thoroughly studied. In this study, the assay was carried out in the presence of increasing concentrations of mono- or

\section{Received June 1, 1989}

To whom correspondence should be addressed: Dr. SENKITI SAKAI

(Te1. 03-812-2111, Ext. 5382) bivalent salts. The association rate constant $\left(\mathrm{k}_{+1}\right)$ and dissociation rate constant $\left(\mathrm{k}_{-1}\right)$ of PRL were determined in order to clarify the mechanism of the action of salts on stimulation of PRL binding. In the preliminary experiments, the introduction of $\mathrm{NaCl}$ or $\mathrm{KCl}$ failed to produce maximal stimulation, which was achieved by adding $\mathrm{CaCl}_{2}$ or $\mathrm{MgCl}_{2}$ at $25 \mathrm{mM}$. Recently, we reported that the rabbit mammary gland contains PRL-binding species with a different molecular weight $\left(\mathrm{M}_{\mathrm{r}}\right)$ (Sakai et al., 1987 ; Murakami et al., 1988). Under different ionic environments, the species of PRL-binding receptor was also analyzed by SDS-polyacrylamide gel electrophoresis (SDS-PAGE) and autoradiography. 


\section{Materials and Methods}

\section{PRL binding assay}

Ovine PRL (NIADDK-oPRL-18, $31 \mathrm{IU} / \mathrm{mg}$ ) was kindly supplied by NIADDK, Bethesda, Md. PRL was iodinated by lactoperoxidase and $\mathrm{H}_{2} \mathrm{O}_{2}$, and its specific activity was about $2.775 \mathrm{MBq} / \mu \mathrm{g}$ (Sakai et al., 1975). Mammary microsomes obtained from mid-lactating New Zealand White rabbits were used. The procedures for the PRL binding assay, the Scatchard analysis, and the time-course kinetics will be described elsewhere (Sakaki and Suzuki, 1989). In the present experiments, the binding buffer was metallic ionfree, and consisted of $25 \mathrm{mM}$ Tris/ $\mathrm{HCl}$ ( $\mathrm{pH}$ 7.4)$1 \mathrm{mM}$ phenylmethylsulfony 1 fluoride $-0.2 \%$ bovine serum albumin. $\mathrm{NaCl}, \mathrm{KCl}, \mathrm{MgCl}_{2}$, and $\mathrm{CaCl}_{2}$ were dissolved in the binding buffer and the $\mathrm{pH}$ was adjusted to 7.4. The final concentrations are shown in the text. The microsomes $(100 \mu \mathrm{g})$ were incubated at $20^{\circ} \mathrm{C}$ for $20 \mathrm{~h}$ with $40,000 \mathrm{cpm}$ of $\left.{ }^{[125} \mathrm{I}\right] \mathrm{PRL}$ in the presence and absence of excess unlabeled PRL $(1 \mu \mathrm{g})$ in a reaction volume of $0.5 \mathrm{ml}$. When the incubation was terminated, $4 \mathrm{~m} 1$ of the binding buffer containing $10 \mathrm{mM}$ $\mathrm{MgCl}_{2}$ was added and the tubes were centrifuged at $2,300 \times \mathrm{g}$ for $10 \mathrm{~min}$ at $4^{\circ} \mathrm{C}$. For the Scatchard analysis, unlabeled PRL from $0.2 \mathrm{ng}$ to $6.4 \mathrm{ng} /$ tube was added in the reaction mixture. To determine the time-dependent PRL binding, the tubes were placed in an ice bath during the preparation and transferred to a water bath to start the reaction. The $\mathrm{k}_{+1}$ was calculated according to the methods described by Shiu and Friesen (1974). The $\mathrm{k}_{-1}$ was calculated according to the methods described by El-Refai (1984). Experiments were performed in triplicate, and each determination was repeated at least twice.

\section{Affinity-labeling, SDS-PAGE and autoradio- graphy}

The procedures for affinity-labeling, SDSPAGE and autoradiography have previously been described (Sakai and Ike, 1987). In brief, the microsomes $(200 \mu \mathrm{g})$ were incubated with 300,000 $\mathrm{cpm}$ of $\left[{ }^{[25} \mathrm{I}\right] \mathrm{PRL}$, as described above. The microsomes were washed once with the binding buffer and twice with $10 \mathrm{mM}$ phosphate buffer (pH 7.4). The PRL-receptor complex was crosslinked with $0.75 \mathrm{mM}$ disuccinimidyl suberate, and was denatured in the presence of $2 \%$ SDS and $100 \mathrm{mM}$ dithiothreitol. The complex was electrophoresed on a $10 \%$ polyacrylamide gel. The dried gel was used for autoradiography. The $M_{r}$ of the PRL receptor was estimated with the SDS-PAGE $\mathrm{M}_{\mathrm{r}}$ marker standards (Bio-Rad, Richmond, Calif.).

\section{Results and Discussion}

The effect of salts and their ionic strength on the binding of PRL was examined, and the results are shown in Fig. 1. The control values were obtained under metallic ion-free conditions. The amount of specific binding of [ $\left.{ }^{125 I}\right]$ PRL was changed greatly by the type of salt and the ionic strength. All salts had biphasic effects on PRL binding proportional to their concentrations: there was a marked increase in

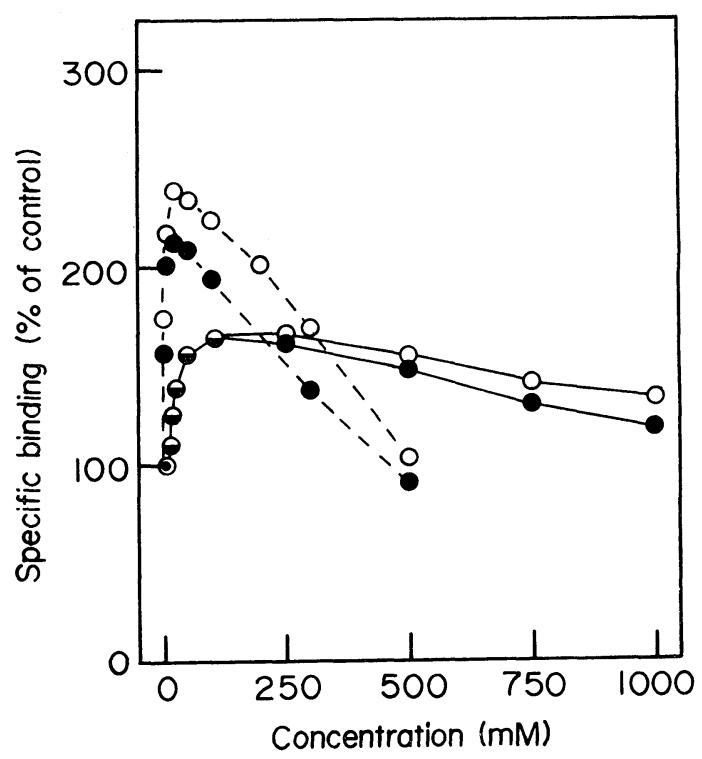

Fig. 1. Effect of various salts on PRL binding. The amount of specific binding of $\left[{ }^{125} \mathrm{I}\right] \mathrm{PRL}$ obtained in the absence of salt was about $2,530 \mathrm{cpm} /$ tube, and this value was taken as $100 \%$. The data represent the mean values obtained from two independent experiments. $\mathrm{KCl}(\bigcirc-\bigcirc), \mathrm{NaCl}(\bigcirc-\bigcirc), \mathrm{CaCl}_{2}(\bigcirc \cdots \bigcirc)$, $\mathrm{MgCl}_{2}$ (-) 
the PRL binding at lower concentrations and a decrease at higher concentrations. $\mathrm{KCl}$ and $\mathrm{NaCl}$ from 0 to $100 \mathrm{mM}$ increased the binding about 1.6-fold. At higher concentrations, both monovalent salts decreased the amount of specific binding slightly. $\mathrm{MgCl}_{2}$ and $\mathrm{CaCl}_{2}$ concentrations at $0 \mathrm{mM}$ to $25 \mathrm{mM}$ enhanced the binding of PRL about 2.1-and 2,4-fold, respectively. At higher concentrations, the amount of specific binding decreased in a linear fashion and, at $500 \mathrm{mM}$, decreased to that of the $0 \mathrm{mM}$ control. The results show that bivalent salts exert a grater effect on promoting the binding of PRL than monovalent salts. These results are consistent with findings in the rabbit mammary gland (Shiu and Friesen, 1974). The effects of salts on PRL binding were slightly different from rat liver PRL receptor (Silverstein and Richard, 1979; Webb et al., 1986). This appears to be due to differences in the PRL-binding species: the $M_{r}$ of PRL-binding components have been reported as 35,000-46,000 for rabbit liver (Haeuptle et al., 1983; Hughes et al., 1983) and rat liver (Borst and Sayare, 1982; Haldosen and Gustafsson, 1987; Katoh et al., 1987). In the present experiments, the amount of specific binding obtained in the presence of $2 \mathrm{mM}$ EDTA was comparable to that observed in the absence of salts. The amount of non-specific binding was always less than $1.2 \%$ of the total radioactivity added.

In the presence of various concentrations of the salts, the $\mathrm{k}_{+1}, \mathrm{k}_{-1}, \mathrm{~K}_{\mathrm{d}}$, and binding capacity were determined from the data for the time-course kinetics and equilibrium binding. Table 1 shows the results obtained in the presence of $\mathrm{NaCl}, \mathrm{CaCl}_{2}$ and $\mathrm{MgCl}_{2}$. Both mono- and bivalent salts had biphasic effects on the change in $K_{d}$. The addition of salts at low concentrations decreased the $\mathrm{K}_{\mathrm{d}}$ for PRL binding and, higher concentrations caused an increase. The $\mathrm{K}_{\mathrm{d}}$ was changed greatly in the presence of bivalent salts. A small $\mathrm{K}_{\mathrm{d}}$ value was obtained in the presence of either $\mathrm{NaCl}$ at $100 \mathrm{mM}$ or

Table 1. Effects of salts on changes in the $\mathrm{k}_{+1}, \mathrm{k}_{-1}, \mathrm{k}_{\mathrm{d}}$, and binding capacity. $($ mean $\pm \mathrm{SD}, \mathrm{n}=3$ )

\begin{tabular}{ccccc}
\hline \hline $\begin{array}{l}\text { Salt } \\
(\mathrm{mM})\end{array}$ & \multicolumn{2}{c}{$\begin{array}{c}\mathrm{k}_{+1} \\
(\text { time-course } \\
\left(\mathrm{nM}^{-1} \mathrm{~h}^{-1}\right)\end{array}$} & $\begin{array}{c}\mathrm{k}_{-1} \\
\text { kinetics }) \\
\left(\mathrm{h}^{-1} \times 10^{2}\right)\end{array}$ & \multicolumn{2}{c}{$\begin{array}{c}\mathrm{k}_{\mathrm{d}} \\
(\text { Scatchard } \\
(\mathrm{pM})\end{array}$} & $\begin{array}{c}\text { Capacity } \\
\text { analysis }) \\
(\mathrm{fmol})\end{array}$ \\
\hline $\mathrm{NaC1}$ & & & & \\
0 & $0.41 \pm 0.05$ & $6.46 \pm 0.63$ & $168 \pm 14$ & $10.2 \pm 0.6$ \\
5 & $0.52 \pm 0.04$ & $6.63 \pm 0.59$ & $137 \pm 12$ & $11.0 \pm 0.3$ \\
25 & $0.65 \pm 0.11$ & $7.02 \pm 0.41$ & $108 \pm 15$ & $11.2 \pm 0.5$ \\
100 & $0.80 \pm 0.09$ & $6.89 \pm 0.29$ & $85 \pm 11$ & $10.9 \pm 0.7$ \\
500 & $0.68 \pm 0.07$ & $6.91 \pm 0.33$ & $105 \pm 12$ & $11.2 \pm 0.9$ \\
100 & $0.51 \pm 0.06$ & $6.95 \pm 0.53$ & $111 \pm 11$ & $11.3 \pm 1.1$ \\
$\mathrm{MgCl}_{2}$ & & & & \\
0 & $0.41 \pm 0.03$ & $6.74 \pm 0.59$ & $169 \pm 13$ & $10.1 \pm 0.4$ \\
5 & $0.95 \pm 0.13$ & $6.85 \pm 0.72$ & $72 \pm 15$ & $11.3 \pm 0.8$ \\
10 & $1.17 \pm 0.09$ & $7.07 \pm 0.51$ & $57 \pm 9$ & $14.4 \pm 1.1$ \\
25 & $1.28 \pm 0.11$ & $6.83 \pm 0.28$ & $54 \pm 10$ & $16.2 \pm 0.4$ \\
250 & $0.56 \pm 0.02$ & $6.11 \pm 0.39$ & $110 \pm 11$ & $16.1 \pm 0.6$ \\
500 & $0.26 \pm 0.04$ & $5.82 \pm 0.21$ & $214 \pm 8$ & $15.8 \pm 0.9$ \\
$\mathrm{CaCl}_{2}$ & & & & \\
0 & $0.42 \pm 0.06$ & $6.55 \pm 0.32$ & $158 \pm 9$ & $10.3 \pm 0.4$ \\
25 & $1.44 \pm 0.12$ & $6.90 \pm 0.49$ & $48 \pm 11$ & $16.2 \pm 0.4$ \\
250 & $0.90 \pm 0.11$ & $6.35 \pm 0.21$ & $74 \pm 9$ & $15.7 \pm 0.8$ \\
\hline
\end{tabular}


bivalent salts at $25 \mathrm{mM}$. By increasing the $\mathrm{NaCl}$ concentration of from $0 \mathrm{M}$ to $1 \mathrm{M}$, the binding capacity was unchanged and was comparable to the $0 \mathrm{mM}$ control. The amount obtained in the presence of bivalent salts at $25 \mathrm{mM}$ was about 1.6-fold larger than for the $0 \mathrm{mM}$ control. The increased binding capacity was maintained with concentrations of $\mathrm{MgCl}_{2}$ from $25 \mathrm{mM}$ to $500 \mathrm{mM}$. The $\mathrm{k}_{+1}$ of PRL binding increased about 2.0-fold, when the $\mathrm{NaCl}$ concentration was increased from $0 \mathrm{mM}$ to $100 \mathrm{mM}$. The $\mathrm{k}_{-1}$ was unaffected by $\mathrm{NaCl}$ concentrations between $0 \mathrm{M}$ and $1 \mathrm{M}$. $\mathrm{CaCl}_{2}$ and $\mathrm{MgCl}_{2}$ at $25 \mathrm{mM}$ enhanced the association rate about 3.4 - and 3.1 -fold, respectively. At higher than $250 \mathrm{mM}$, the $\mathrm{k}_{+1}$ decreased greatly. $\mathrm{Ca}^{2+}$ - or $\mathrm{Mg}^{2+}$ dependent modulation of receptor affinity has been shown in other receptor systems (Anderson and Reichert, 1982; Antoni and Chadio, 1989; Loeb and Drickamer, 1988).

The apparent $\mathrm{M}_{\mathrm{r}}$ of free PRL was about $26,000 \pm 1,200 \quad($ mean $\pm S D, n=4)$ and has been subtracted from the $\mathrm{M}_{\mathrm{r}}$ of the complex. As shown in Fig. 2, the mammary gland con- tained three species of PRL-binding proteins. We confirmed our previous findings (Murakami et al., 1988; Sakai and Ike, 1987). In the present study, the band of $M_{r} 22,000$ could also be detected in the lane of the noncross-linked control. The receptor with an $\mathrm{M}_{\mathrm{r}}$ of $78,000 \pm 2,400$ or of $34,500 \pm 2,200$ receptor was specific for the binding of PRL. The $M_{r} 34,500$ receptor could be detected on the autoradiogram regardless of the presence of either mono- or bivalent salts. The $\mathrm{M}_{\mathrm{r}} 78,000$ receptor appeared on the autoradiogram in the presence of bivalent salts.

It is apparent that bivalent cations modulate the affinity as well as the availability of the receptor for PRL binding. The mechanism of the effect by bivalent cations is not well understood. As shown here, the introduction of bivalent cation accelerated the rate of association of PRL with the receptor greatly. The binding of PRL to the $M_{r} 78,000$ receptor occurred in the presence of $\mathrm{Ca}^{2+}$ or $\mathrm{Mg}^{2+}$. Taken together, it appears that bivalent cation interacts with the PRL-binding site of the

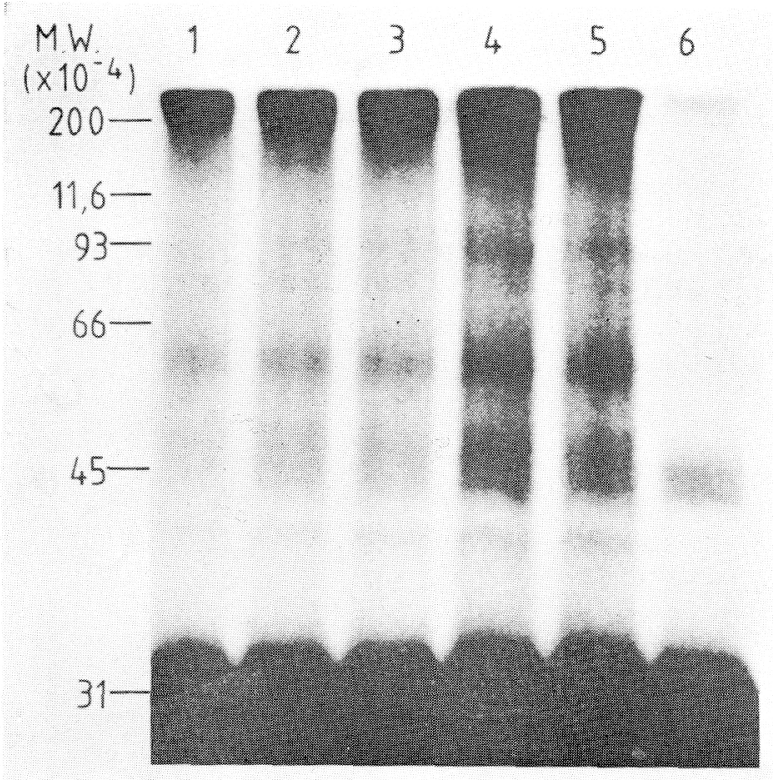

Fig. 2. Autoradiography of covalently cross-linked PRL-receptor complex. Hundred $\mu \mathrm{g}$ of protein was applied to each lane. Radioactivity of total (and non-specific) binding was as follows; lane 1, control, 9,300 (560); lane 2, $\mathrm{NaCl}, 12,600$ (480); lane 3, $\mathrm{KCl}$, 13,300 (460); lane 4, $\mathrm{MgCl}_{2}$, $16,200(1,100)$; lane $5, \mathrm{CaCl}_{2}$, $17,000(1,300)$; and lane 6 , noncross-linked samples of lane 5 . The concentration of mono- or bivalent cation was at $100 \mathrm{mM}$ or at $25 \mathrm{mM}$, respectively. The migrating positions of the high and low $\mathrm{M}_{\mathrm{r}}$ protein standards are shown in the figure. 
$\mathbf{M}_{\mathrm{r}} 78,000$ receptor to stabilize a conformation favoring the binding of PRL. At high concentrations, the $\mathrm{k}_{+1}$ decreased greatly, in the presence of bivalent cations. This is probably due to the alteration of the reaction environment (Sakai and Suzuki, 1989). Both $\mathrm{Ca}^{2+}$ and $\mathrm{Mg}^{2+}$ ions at high concentrations are known to have a chaotropic action.

\section{Acknowledgements}

We thank Dr. Hassan Salari for comments during the preparation of this manuscript. The work was supported, in part, by grants from the Ministry of Education, Science and Culture of Japan (62560262 and 63560256).

\section{References}

Andersen, T. T., and L. E. Reichert, Jr (1982). Follitropin binding to receptors in testis. $J$. Biol. Chem. 257, 11551-11557.

Antoni, F. E. and S. E. Chadio (1989). Essential role of magnesium in oxytocin-receptor affinity and ligand specificity. Biochem. $J$. 257, 611-614.

Borst, D. W. and M. Sayare (1982). Photoactivated cross-linking of prolactin to hepatic membrane binding sites. Biochem. Biophys. Res. Comm. 105, 194-201.

E1-Refai, M. F. (1984). Assay of soluble receptors. In: Receptor Biochemistry and Methodology (J. C. Venter and L. C. Harrison eds.), Alan R. Liss, NY, vol 1, pp. 99-108.

Haeuptle, M-. T., M. L. Aubert, J. Djiane and J.. P. Kraehenbuh1 (1983). Binding sites for lactogenic and somatogenic hormones from rabbit mammary gland and liver. J. Biol. Chem. 258, 305-314.

Haldosen, L-.A. and J-.A. Gustafsson (1987). Characterization of hepatic lactogen receptor. J. Biol. Chem. 262, 7404-7411.
Haro, L. S. and F. J. Talamantes (1985). Interaction of mouse prolactin with mouse hepatic receptors. Mol. Cell. Endocrinol. 41, 93-104.

Hughes, J. P., J. S. A. Simpson and H. G. Friesen (1983). Analysis of growth hormone and lactogenic binding sites cross-linked to iodinated human growth hormone. Endocrinology 112, 1980-1985.

Katoh, S. Raguet, J. Zachwieja, J. Djiane and P. A. Kelly (1987). Hepatic prolactin receptors in the rat: characterization using monoclonal antireceptor antibodies. Endocrinology 120, 739-749.

Loeb, J. A. and K. Drickamer (1988). Conformational changes in the chicken receptor for endocytosis of glycoproteins: modulation of ligand-binding activity by $\mathrm{Ca}^{2+}$ and $\mathrm{pH} . J$. Biol. Chem. 263, 9752-9760.

Murakami, H., F. Ike, K. Kohmoto and S. Sakai (1988). Monoclonal antibody detection of prolactin-binding subunits in the rabbit mammary gland. Biochem. J. 256, 917-922.

Sakai, S., K. and F. Ike (1987). Two separate receptors for prolactin in the rabbit mammary gland. Endocrinol. Japon. 34, 863-870.

Sakai, S. and M. Suzuki (1989). Interaction between prolactin and rabbit mammary prolactin receptor in the presence of environmentmodifying agents. Endocrinol. Japon. 36, 727731.

Sakai, S., K. Kohmoto and T. Johke (1975). A receptor site for prolactin in lactating mouse mammary tissues. Endocrinol. Japon. 22, 379387.

Shiu, R. P. C. and H. G. Friesen (1974). Properties of a prolactin receptor from the rabbit mammary gland. Biochem. J. 140, 301-311.

Silverstein, A. M. and J. F. Richards (1979). Characterization of prolactin binding by membrane preparations from rat liver. Biochem. J. 178, 743-751.

Webb, C. F., H. F. Cadman and M. Wallis (1986). The specificity of binding of growth hormone and prolactin to purified plasma membranes from pregnant-rabbit liver. Biochem. J. 236, 657-663. 